Volume 12, Nomor 2, November 2020, pp 256-264 Copyright (C) 2017

Jurnal Akuntansi, Program Studi Akuntansi, Fakultas Ekonomi, Universitas Kristen Maranatha. ISSN 2085-8698 | e-ISSN 2598-4977. http://journal.maranatha.edu

\title{
The Impact Analysis of Return on Asset, Leverage and Firm Size to Tax Avoidance
}

\author{
Endah Purnama Sari Eddy \\ Fakultas Ekonomi Program Studi Akuntansi Universitas Kristen Maranatha \\ (Jl. Prof. drg. Suria Sumantri, MPH No. 65, Bandung) \\ endah.eps@gmail.com \\ Aurora Angela \\ Fakultas Ekonomi Program Studi Akuntansi Universitas Kristen Maranatha \\ (Jl. Prof. drg. Suria Sumantri, MPH No. 65, Bandung) \\ aurora.ang31@yahoo.com \\ Erna \\ Fakultas Ekonomi Program Studi Akuntansi Universitas Kristen Maranatha \\ (Jl. Prof. drg. Suria Sumantri, MPH No. 65, Bandung) \\ erna.ethan@yahoo.com
}

\begin{abstract}
This study aims to analyze the effect of Return on Assets, Leverage and Company Size Against Tax Avoidance. The independent variables are Return On Assets, Leverage and Company Size while the dependent variable is Tax Avoidance. The population in this study uses the financial statements of manufacturing companies listed on the Indonesia Stock Exchange from 2013-2017. Samples collected using Purposive Sampling Method. This study uses the Multiple Regression Analysis Method. Based on the hypothesis test, the significance value of > 0.05 was acquired, which means that Ho accepted, conclude that there are no influence of Return On Asset (ROA), Leverage and Firm Size against Tax Avoidance.
\end{abstract}

Keywords: Return On Asset, Leverage, Firm Size, and Tax Avoidance 


\begin{abstract}
Abstrak
Penelitian ini bertujuan untuk menemukan bukti empirik mengenai seberapa besar pengaruh Return On Asset, Leverage dan Ukuran Perusahaan Terhadap Tax Avoidance. Variabel independennya adalah Return On Asset, Leverage dan Ukuran Perusahaan sedangkan variabel dependennya adalah Tax Avoidance. Populasi pada penelitian ini menggunakan laporan keuangan perusahaan manufaktur yang terdaftar di Bursa Efek Indonesia dari tahun 2013-2017. Sampel yang dikumpulkan menggunakan Purposive Sampling Method. Penelitian ini menggunakan Metode Analisis Regresi Berganda. Berdasarkan uji hipotesis, didapatkan nilai signifikansi > 0.05, yang berarti bahwa Ho diterima, yang berarti bahwa tidak terdapat pengaruh Return On Asset (ROA), Leverage dan Ukuran Perusahaan terhadap Tax Avoidance.
\end{abstract}

Kata Kunci: Return On Asset, Leverage, Firm Size, dan Tax Avoidance

\section{INTRODUCTION}

The advance technology and economic growth has pushed the competitions and innovation among entrepreneurs. That condition contributes to the tax growth which has positive impact to the country. According to Mayasari (2015) The company's contribution on taxation has a great deal on a country's tax income if the company has the awareness on paying the taxes in the right amount and in the right time. Problems might arise as the result of prominence differences between the entrepreneurs as tax payer and the government as fiscus, where taxes were seen as company's profit reducer. This kind of differences making the entrepreneur applying tax avoidance practice. The phenomenon of tax avoidance in Indonesia can be seen from our tax ratio which is only $10.8 \%$ of GDP and when compared to the lowest ASEAN countries. The low tax ratio is because the number of taxpayers who carry out their obligations is still small. (okezone.com, 2018)

Faizah and Adhivinna, 2017 stated that tax avoidance is an act of legal and safe practice conducted by the tax payers without compromising the taxation law because the technics used were by utilizing the weaknesses of taxation laws and orders. The goals of a company in doing tax avoidance are to minimize tax liability and maximizing the profit. The are some ways in doing tax avoidance, some of those are through ROA (Return on Asset) and Leverage. (Rizal dan Irwansyah; 2017)

ROA (Return On Asset) is an analysis technic that mostly used in measuring the whole company's operational effectivity. This ratio could measure the company's capability with all the invested fund in current assets used on the company's operation to make profits. (Sartono; 2011).

According to Dewinta \& Setiawan (2016), ROA (Return On Asset) is a net profit measurer based on the level of the company's assets optimization. The higher the ROA rate, the higher the company's profit that reflects the better company's assets management practice.

Yuyetta (2009), The enhancement of Leverage shows two signals, those both good news and bad news. The Leverage enhancement shows good news when that enhancement reflects the company's good ability in managing loans that could produce big profit which escalate the company's worth. On the contrary, this could reflect bad news when a manager doing Leverage enhancement based on 
scrutiny, not based on efficiency effort. The debt ratio in this research is proxied as DER (Debt to Equity Ratio) which is the comparison between the company's longterm loans value and the company's own capital.

Some research related to the effect of Return On Asset, Leverage and Firm Size to Tax Avoidance, one of those conducted by Faizah and Adhivinna (2017) the result shows that Return On Asset (ROA) affecting the tax avoidance practice conducted by manufacturing companies listed at the Indonesia Stock Exchange (IDX) during the period of 2011-2015. While the Leverage act and Firm Size has no effect on tax avoidance practice. To be different from the previous research conducted by Fachrizal, Pratomo dan Kurnia (2018) which stated that simultaneously, Tax Avoidance, Leverage (DER), and Firm Size do significantly affecting Firm Value. While partially Tax Avoidance has negative significant effect against Firm Value, Leverage (DER) not affecting Firm Value while Firm Size has positive significant effect to Firm Value.

Based on those mentioned facts, the researcher interested in conducting research on "The Impact Analysis of Return on Asset, Leverage and Firm Size to Tax Avoidance"

\section{THEORETICAL FRAMEWORK AND HYPHOTESIS}

\section{Return On Asset (ROA)}

According to Kurniasih \& Sari (2013) on Faizah and Adhivinna (2017) Return On Asset (ROA) is an indicator that reflects the company's financial performance, the higher value of Return On Asset (ROA), the better the company's performance. Return On Asset (ROA) is related to the net profit generated by the company and the tax liability. Sartono (2011) in Faizah and Adhivinna (2017) stated that the ratio of rentability/ profitability is the company's ability in acquiring profit in relation between sales, assets, and capital. Return On Asset (ROA) is a method used to calculate profitability. Return On Asset $(R O A)$ is an analysis technic that mostly applied to measure the company's operational effectivity. This ratio measures the company's ability to generate profit using the invested fund in current asset on their operation. According to Dewinta \& Setiawan (2016) Return On Asset (ROA) in Faizah and Adhivinna (2017) is a net profit measurer that generated from measurement on how big the company utilizing its asset. The higher the Return On Asset (ROA), the higher the company's profit acquired, the better the company's asset management. As stated by Adyani and Sampurno (2017) Return On Asset (ROA) is one of many profitability ratio applied to measure the company's effectivity in generating profit by utilizing its asset. Based on the Bank of Indonesia's term, the good standard of Return On Asset (ROA) is around 1,5\%. The bigger Return On Asset (ROA) shows good company's performance because of the bigger return.

Calculation on Return On Asset ROA consist of:

1. Calculating the Earning Before Tax (EBT) of company's profit (bank) before deducted by tax.

2. Calculating all the assets owned by bank consisted of current asset and fixed asset.

Mathematically, ROA can be formulated as follow :

$\mathrm{ROA}=\frac{\text { Earning Before Tax }}{\text { Total Assets }} \times 100 \%$

\section{Leverage (Debt to Equity Ratio)}

Fahmi (2012) defines Leverage ratio (DER) as measuring the company's financing level by loans. While according to Harahap (2010) Leverage (DER)is a ratio that reflect 
the relation between the company's debt to capital and asset. Debt to Equity Ratio measurement is done by comparing all the debts with all equities. According Harahap (2010), this ratio can be calculated by this formula:

\section{Debt to Equity Ratio $($ DER $)=$ Total debts / Total company's capital}

Leverage is a part of financial ratio that showing the relation between debts to company's capital and asset. Leverage shows how far the company is financed by loans or external party with company's ability being pictured by capital. Ngadiman \& Puspitasari (2014), stated that leverage is fund usage by external party in the state of loans to fund the company's investment or asset. The addition of loans will generate interest that has to be paid by the company. The interest will reduce the earning before $\operatorname{tax}$ so that also reducing the tax liability that must be paid by the company.

\section{Firm Size}

According to Silaban (2013) the purpose of company's establishment, were commonly known by public to acquire profit as much as possible. The prominence of company is not only to acquire profit but also to enhance the wealth of the owner, the shareholders and upgrading the company's value. Company's value could show the state of a company, whether it is good or bad. The higher the company's value, then the better the company's state being seen. When a company looks good in the eyes of investors, then it could become the reason for them to invest in that company (Analisa, 2011) in Fahrizal, Pratomo and Kurnia (2018). Pratiwi (2011) in Fahrizal, Pratomo and Kurnia (2018) stated that the increased company's value could attract the investors to make investment. For investors who interested to make investment, the profit gain that will be generated from the investment in the form of capital gain and dividend which are part of the shared profit to the shareholders is the sought-after aim. Hormati (2009) stated that Firm Size is a scale that classify the size of a company by using some bases such as total asset, log size, and market share value. According to Kurniasih \& Sari (2013) the firm size is classified into three categories: Large Firm, Medium Firm and Small Firm. Ngadiman and Puspitasari (2014) stated that the classification of Firm Size is based on the company's total asset. The bigger the total asset shows that the company has good prospect in the long term. Company with big asset show that it is more consistent and capable in generating profit compared to those with small total asset. Tobin's $Q$ is an indicator to measure the company's performance, especially about the company's value that reflect a management performance in managing the company's asset, so that the investors could predict the share price development potential and the investment growth potential (Sudiyatno and Puspitasari, 2010). So in general Tobin's $Q$ is a comparison between market value of all outstanding shares plus Debt devided by Total Aset stated in book value, with the result which conclude that if Q-ratio above one, shows investment in asset generates profit that giving higher value instead of investment expenditure, this will attracting new investments. If Q-ratio is below one, then investment in asset is not interesting (Herawaty, 2008). One policy that could enhance the company's value is by Tax Avoidance practice (legal tax avoiding acts) because by doing so, the tax liability become smaller, and as the tax liability has been reduced then it would impact the increased profit so that it will escalate the company's value.

\section{Tax Avoidance}

According to Pohan (2013), tax avoidance is a legally and safe act by tax payer because it is not compromising the taxation terms and conditions where the method and technic used were tend to utilized the 
weaknesses (grey area) of the taxation laws and policies itself, to reduce the tax liability. The Tax Avoidance measurement uses Cash Effective Tax Ratio (CETR) model that hopefully can identifies the aggressiveness of company's tax (Chen et al. 2010) with formula as follows:

\section{CETR = Tax Payment $/$ Earning Before Tax}

Tax Avoidance is an effort conducted by tax payer to reduce the tax liability by utilizing the weaknesses on laws and policies (Faizah and Adhivinna; 2017). According to Ngadiman \& Puspitasari (2014) tax avoidance has secretive elements those reducing a company's transparency, so that it is necessary to set a good company governance with the existence of institutional ownership. Institutional share ownership hoped to be able to give roles for the institutions to observe, to oversee and to discipline the company so that they will not do any harmful act to the company.

\section{Hypothesis}

The hypothesis formulation on this research is as follows:

$\mathrm{H}_{1}=$ There is an influence the effect of Return On Asset, Leverage, Firm Size on Tax Avoidance.

Research model presented on the picture below:

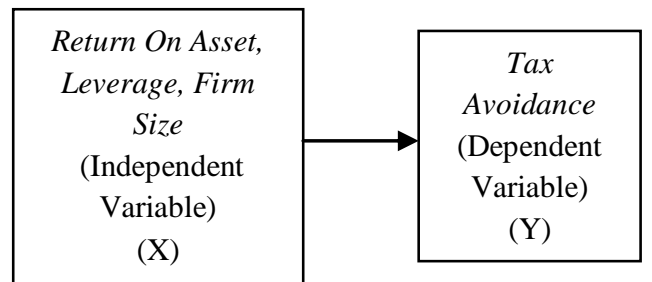

Picture 1

Research Model

\section{Research Method}

\section{Population and Sample}

Population on this research are the manufacturing companies listed at the Indonesia Stock Exchange in the year 20142017. The method applied on this research is purposive sampling from manufacturing companies during 2014-2017. The analysis technic applied on this research is descriptive statistical analysis and regression data panel with the equation of regression data panel as follows:

Legends:

$\mathrm{Y}=$ Firm Value

$\alpha=$ Constant

$\beta 1, \beta 2, \beta 3=$ regression coefficient of each independent variable

$\mathrm{X} 1$ it $=$ Tax Avoidance

Sample determination on this research is using purposive sampling method, where a certain number of samples were collected from issuer population with certain consideration. (Sugiono, 1999).

The population used in this research is all manufacturing companies those listed at the Indonesia Stock Exchange. The population used in this research is 148 companies. The research's sample were determined using the nonprobability sampling with purposive sampling technic, so that the sample used in this research are 56 companies.

\section{Dependent Variable}

Tax avoidance is a company effort to reduce the tax liability that must be paid without compromising the taxation laws. The tax avoidance estimated measurement in this research is Cash Effective Tax Rate (CETR) model, which hoped to be able to identify the company's tax planning as stated by Ngadiman and Christiany (2014). Cash Tax Paid data was generated from the amount of the company's tax liability while Pre-tax Income was generated from Earning before tax stated in the consolidated comprehensive annual report . 


\section{Independent Variable \\ a. Return On Asset (ROA)}

Return On Asset (ROA) is a comparison between net profit and total asset in the end of period which will be used as indicator of the company's ability in generating profit as stated by Waluyo, and friends. (2015).

\section{b. Leverage}

Leverage is utilization of loans both long term and short term to finance the company's operational and assets which is measured using the debt to equity ratio (Ngadiman \& Puspitasari, 2014).

\section{c. Firm Size}

The Firm size on this research is measured by using total asset as the firm size was proxied with total asset Ln. The usage of natural $\log (\mathrm{Ln})$ in this research is meant to be able to reduce the data over fluctuation without altering the real original proportion value.

\section{Data Collection Technic}

To get the data required on this research, the writer uses the documentation observation technic. This research uses secondary data which are the indirectly acquired research data resources. The data were acquired from the financial report of manufacturing companies listed at the IDX (Indonesia Stock Exchange) from 2014 until 2017 from the IDX official website (www.idx.co.id). According to Gujarati (2006) regression analysis is a study against the relation of a variable the explained variable to one or two variables which are the explanatory. The significance level of $5 \%(\alpha=0,05)$ with the truth level of (n-2), which defines that the conclusion probability as big as 5\%. The criteria of exception or Ho denial are defined as follows:

- Ho rejected if $p$ value ( $\operatorname{sig}) \leq \alpha$

- Ho accepted if $p$ value ( $s i g)>\alpha$
The statistical hypothesis are as follows:

- Ho : $\beta=0$ means there are no influence of Return On Asset, Leverage, Firm Size against Tax Avoidance.

- Ha : $\beta \neq 0$ means there are influence of Return On Asset, Leverage, Firm Size against Tax Avoidance.

Which means that the conclusions based on criteria of Ho acceptance or denial are as follows:

- Denied Ho means Return On Asset, Leverage, Frim Size have influence against Tax Avoidance.

- Accepted Ho means Return On Asset, Leverage, Firm Size have no significant influence against Tax Avoidance.

The research conducted against manufacturing companies listed at the Indonesian stock Exchange, with the research period of 6 months.

\section{CONCLUSION, IMPLICATION, AND SUGGESTIONS}

\section{Partial Test (statistical test $t$ )}

Herewith the partial test with the purpose to see whether there are influence of Return On Asset (ROA), Leverage, Firm Size against Tax Avoidance. The first hypothesis on this research shows that there are influences of Return On Asset (ROA), Leverage dan Firm Size against Tax Avoidance. 
Table 1

Partial Test

Coefficients $^{\mathrm{a}}$

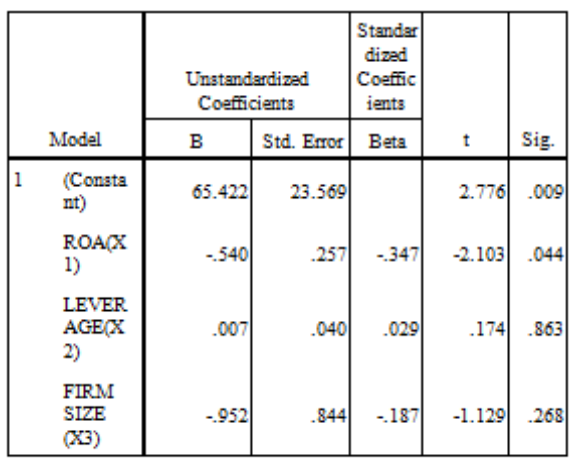

a. Dependent Variable: Tax Avoidance

Based on the table 1, significance value of ROA (Return On Asset) X1 as $0.044<0.05$ which means Ha1 was accepted, that conclude that there are influences of ROA (Return On Asset) against Tax Avoidance. Also, as other variables $\mathrm{X} 2$ as leverage and firm size. The result from the table above shows that the Leverage significance level of 0.863 means $\mathrm{H} 01$ was accepted and $\mathrm{Ha} 1$ was denied, conclude that $0.863>0,05$ means that Ha1 was denied, which conclude that there is no influence of Leverage against Tax Avoidance. Other than that the $\mathrm{X} 3$ variable which shows the significance level of $0.268>0,05$ which means that Hal was denied, conclude that there are no influence of Firm Size has no effect Tax Avoidance.
Table 2

Simultaneous Test

Coefficients $^{\mathrm{a}}$

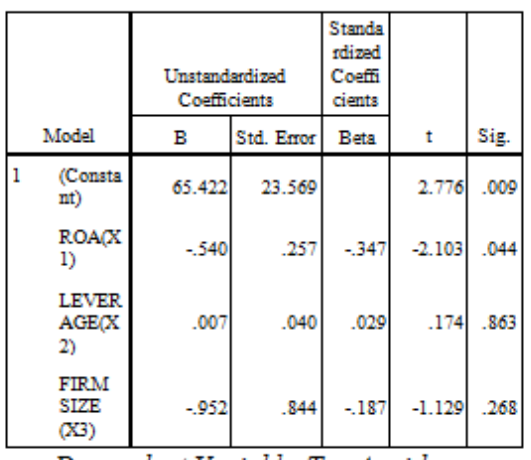

a. Dependent Variable:Tax Avoidance

Based on the table above then, the regression equation would be as follows:

$$
\mathrm{Y}=\mathrm{a}+\mathrm{b} 1 \times 1+\mathrm{b} 2 \times 2+\mathrm{b} 3 \times 3+\mathrm{e}
$$

Where:

$$
\begin{gathered}
\mathrm{Y}=65.422-0.540 \mathrm{X} 1+0.007 \mathrm{X} 2- \\
0.952 \mathrm{X} 3+\mathrm{e}
\end{gathered}
$$

Which means that:

a. If other variables are being constant, then the Tax Avoidance value is 65,422

b. If the X1 variable (Return On Asset) increased by 1 point, then it will reduce the Tax Avoidance variable as of 0.540 points

c. If the X2 variables (Leverage) increased by 1 point, then it will add up the Tax Avoidance variable as of 0,007 points

d. If the X3 variables (Firm Size) increased by 1 point, then it will reduce the Tax Avoidance variable as of 0,952 points.

The tested hypothesis is:

Ha1: There are influences of Return On Asset (ROA), Leverage and Firm Size against Tax Avoidance. 


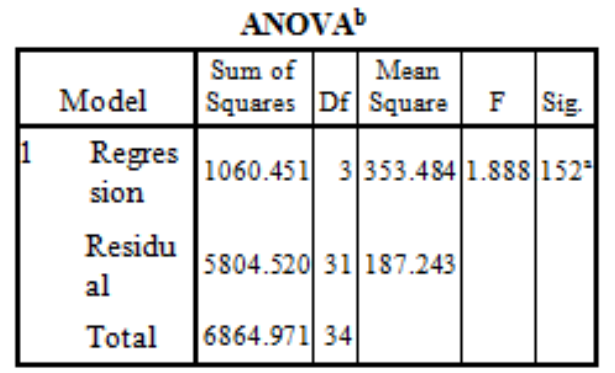

a. Predictors: (Constant), FIRM $\operatorname{SIZE}(\mathrm{X} 3), \operatorname{ROA}(\mathrm{X} 1), L E V E R A G E(X 2)$

Based on the above table, the acquired significance value of 0.152 which means that Ha1 was denied, conclude that there are no influence of Return On Asset (ROA), Leverage and Firm Size against Tax Avoidance.

\section{CONCLUSION AND SUGGESTIONS}

\section{Conclusion}

Based on the hypothesis test, the significance value of $>0.05$ was acquired, which means that Ho accepted, conclude that there are no influence of Return On Asset (ROA), Leverage and Firm Size against Tax Avoidance.

\section{Suggestions}

For the forthcoming researchers:

a. To conduct research against other subdepartments at Indonesia Stock Exchange so that the influence of Return On Asset (ROA), Leverage and Firm Size against Tax Avoidance can be observed on other kind of business types.

b. Acquire additional data by using the longer year period so that the studied matter has more supporting data to produce a more generalized outcome.

\section{References}

Adyani, Lyla Rahma dan Sampurno, Drs. R. Djoko, MM. 2017. Analisis Faktor - faktor Yang Mempengaruhi Profitabilitas (ROA).

Bhuiyan, dan Afzal Ahmad. 2011. Tax Evasion and Avoidance Crimes - A Study on Some Corporate Firms of Bangladesh. Eastern University and International Islamic University Chittagong Working Paper.

Dewi, Made Pratiwi. (2011). Pengaruh Struktur Modal dan Struktur Kepemilikan terhadap Free Cash Flow dan Kebijakan Dividen pada Perusahaan Go Public di BEI. Tesis Program Pasca Sarjana Universitas Udayana Denpasar.

Dewinta, I. A. R \& Setiawan, P. E. 2016. Pengaruh Ukuran Perusahaan, Umur Perusahaan, Profitabilitas, Leverage dan Pertumbuhan Penjualan Terhadap Tax Avoidance. E Jurnal Akuntansi Universitas Udayana, Vol. 14. No. 3.

Fahmi, Irham. (2012). Analisis Laporan Keuangan (Cetakan ke-2). Bandung: Alfabeta.

Faizah, Siti Nur dan Adhivinna, Vidya Vitta. 2017. Pengaruh Return On Asset, Leverage, Kepemilikan Institusional dan Ukuran Perusahaan Terhadap Tax Avoidance. Jurnal Akuntansi Vol.5 No. 2. Yogyakarta.

Gujarati, Damonar. 2006. Dasar - dasar Ekonometrika. Penerbit Erlangga, Jakarta.

Harahap, Sofian Safri. (2010). Analisis Kritis Atas Laporan Keuangan. Jakarta: Rajawali Persada.

Herawati, Titin. 2013. Pengaruh Kebijakan Dividen, Kebijakan Hutang, dan Profitabilitas terhadap Nilai Perusahaan. Jurnal Manajemen, 2(2), pp:1-18. Hoque, Md. Jahirul, Mohammad Z.H.

Hormati. (2009). Karakteristik Perusahaan Terhadap Kualitas Implementasi 
Corporate Governance. Jurnal Keuangan dan Perbankan, 288-298. Kurniasih, Tommy dan Maria M.Ratna Sari. (2013). Pengaruh Return on Assets, Leverage, Corporate Governance, Ukuran Perusahaan Dan Kompensasi Rugi Fiskal Pada Tax Avoidance". Buletin Studi Ekonomi. (18). hal. 58-66.

Mayangsari, Veronica Ria. 2015. Analisis Faktor-Faktor yang Mempengaruhi Penghindaran Pajak Perusahaan yang Terdaftar di Bursa Efek Indonesia. Skripsi. Universitas Diponegoro Semarang.

Ngadiman dan Puspitasari, C. 2014. Pengaruh Leverage, Kepemilikan Institusional dan Ukuran Perusahaan terhadap Penghindaran Pajak (Tax Avoidance) pada Perusahaan Sektor Manufaktur yang Terdaftar di BEI Tahun 2010-2012. Jurnal Akuntansi Vol. XVIII. No. 03.

Novalius, Feby. 2018. Rasio Pajak RI Masih 10,8\%, Sri Mulyani: Terendah

se Asean di https://economy.okezone. com/read/2018/02/07/20/1855912/ra sio-pajak-ri-masih-10-8-sri-mulyaniterendah-se-asean (diakses 17 Septem-ber).

Puspitasari, Elen, dkk.(2010). Tobin's Q dan Altman Z-score Sebagai Indikator Pengukur Kinerja Perusahaan, Kajian Akuntansi | Volume 2 Nomor 1 (2010) ISSN 1979-4886 Hal. 9 - 21.

Rizal dan Irwansyah, Bella. 2017. Pengaruh Leverage, Profitability, Ukuran perusahaan dan Proporsi Kepemilikan Institusional Terhadap Tax Avoidance. Vol. 19, No.1.

Sartono, Agus. 2011. Manajemen Keuangan Teori dan Aplikasi Edisi 4. Yogyakarta: BPFE Yogyakarta.

Sugiyono.2006. Metode Penelitian Kuantitatif Kualitatif Dan $R \& D$. Bandung : Penerbit CV. Alfabeta.
Waluyo, dkk. 2015. Pengaruh Return On Assets, Leverage, Ukuran Perusahaan, Kompensasi Rugi Fiskal dan Kepemilikan Institusi Terhadap Penghindaran Pajak. Jurnal Akuntansi Vol. XVII.

Yuyetta, Etna Nur Afri. (2009). Pengaruh Leverage Terhadap Nilai Perusahaan Pada Masa Krisis. Jurnal Akuntansi dan Auditing, 2 (5). 